удК 316.343:63-051]:329.71(497.1)"1945/1953"

DOI https://doi.org/10.31212/tokovi.2018.3.mil.63-86

Оригинални научни рад

Примљен: 5. 10. 2018.

Прихваћен: 16. 11. 2018.

Srđan MILOŠEVIĆ

Institute for Recent History of Serbia

srdjan.milosevic@inis.bg.ac.rs

\title{
The Role of the Yugoslav Popular Front in Implementing Communist-Style Measures in Yugoslav Rural Areas (1945-1953)*
}

\begin{abstract}
After World War II, the Yugoslav Popular Front (PF) developed extensive activity in the rural areas of Yugoslavia, following the line set by the ruling Communist Party (CPY). It was only from 1948/49 that the Party itself emerged from the rear into the front line of the struggle for the "socialist reconstruction of rural areas". Due to the fact that the issues concerning the policy of the Yugoslav Government toward the peasantry had played an important role in the breakup between Yugoslavia and the USSR (1948), both the PF and the CPY intensified their activities in the rural areas and among the peasantry, in order to disprove the Soviet accusations.
\end{abstract}

Key words: Yugoslavia (1945-1953), Communists, Socialism, Yugoslav Popular Front, Peasantry, Rural Areas

\section{Introduction}

The post-WWII Yugoslav rural community was the mise-en-scène of major structural changes and turmoil, agrarian reform, colonization, compulsory collection of agricultural products by the state, and collectivization, being the most remarkable ones. The rural environment was also

This article is a contribution to the project Transition and transformation - Historical Heritage and National Identity in Serbia in the 20th Century, No 47019, financed by the Ministry for education, science and technological development of the Republic of Serbia. 
the main source of human and material forces for the reconstruction and early development of the whole country. The role of the peasantry and of agriculture ranged from very basic tasks (such as food production, organized through a system of compulsory collection of the agricultural products) to the specific economic position of agriculture in relation to industry (non-equivalent exchange between the two). The pressure brought to bear on the peasantry and agriculture caused numerous "capillary" acts of peasant revolt, resistance, and development of various fraudulent strategies aimed at outwitting the authorities. Attempts to collectivize individual agricultural producers, which were particularly enforced after the 1948 Cominform (IB) Resolution (that heavily accused the Yugoslav communists of taking an "opportunistic attitude" toward the peasants), ended up in a colossal failure already in 1950, but collectivization was definitely abandoned only in 1953. All these issues have been researched and explained comprehensively in a vast body of academic writings. ${ }^{1}$

From the very beginning, in the mid 1930s the political nature of the Popular Front wasn't unquestionable. For instance, according to Georgy Dimitrov, "a special 'democratic intermediate stage"” was inconceivable, while Palmiro Togliatti, reacting on than emerging Spanish Popular Front, argued that it was "a 'new type of democratic republic' which was very unlike a bourgeois democratic republic, and that this republic... would have destroyed the material basis of fascism (something Dimitrov believed only Soviet power could achieve)". ${ }^{2}$ However, under the signifi-

1 For the main outlines of the post-WWII agrarian and peasant politics in Yugoslavia see: Dragan Veselinov, Agrarno pitanje u Jugoslaviji: teorijsko-empirijska analiza položaja i uloge seljačkog gazdinstva u agrarnoj politici i privrednom razvoju Jugoslavije od 1918. do 1980. godine, (Beograd: Borba, 1981); Nikola Gaćeša, Agrarna reforma i kolonizacija u Jugoslaviji 1945-1948, (Novi Sad: Matica srpska, 1984); Dragan Veselinov, Sumrak seljaštva, (Beograd: Ekonomika, 1987); Vera Kržišnik-Bukić, Cazinska buna: 1950, (Sarajevo: Svjetlost, 1991); Момчило Павловић, Српско село 1945-1952: откуn, (Београд: Институт за савремену историју, 1998); Melissa Bokovoy, Peasants and communists: politics and ideology in the Yugoslav countryside: 1941-1953, (Pittsburgh: University of Pittsburgh Press, 1998); Вера Гудац, Аграрна политика ФНРЈ и сељаштво у Србији 1949-1953, (Београд: Завод за уџбенике и наставна средства, 1999); Јелена Попов, Драма на војвођанском селу (19451952): обавезни откуп пољопривредних производа, (Нови Сад: Платонеум, 2002); Ivana Dobrivojević, Selo i grad. Transformacija agrarnog društva Srbije 19451955, Beograd: Institut za savremenu istoriju, 2013); Срђан Милошевић, “Аграрна политика у Југославији 1945-1953”, (Doctoral Thesis, University of Belgrade, Faculty of Philosophy, August 2015).

2 Donald Sassoon, "Togliatti, Italian Communism and the Popular Front", The Polupar Front in Europe, eds Helen Graham and Paul Preston, (London: Macmillan, 1987), 142-143. 
cantly changed political circumstances, the Communist Party of Yugoslavia (CPY) was the most influential member of this coalition of the parties, but both the PF and the CPY had their own separate structures, organizational forms and basic documents, ${ }^{3}$ although in 1949 , at the Third Congress, the PF adopted the Program of the CPY as its own. ${ }^{4}$ This provides a basis for separate research of the two political formations, the former being the subject of this article.

The historiography on the PF is characterized by two major features: 1) disproportionate interest for the period before 1945 and 2) regional approach (common Yugoslav perspective remained less elaborated). The body of academic literature becomes much thinner when it comes to topics concerning the involvement of the PF organizations in implementing the agrarian and peasant policy that the Yugoslav communists were molding for the rural areas. ${ }^{5}$ Almost the only exception is a thorough research by Jelena Popov, who also adopted a regional approach. ${ }^{6}$ An exception is a recently defended $\mathrm{PhD}$ thesis thematizing the life and political activity of Dr. Blagoje Nešković, who was head of the PF Secretariat from 1948 to $1952 .^{7}$

3 Statut Narodnog fronta Jugoslavije, (Sarajevo: Komisija za agitaciju i štampu Glavnog odbora NF za Bosnu i Hercegovinu, 1950).

4 On the ambiguous relation between CPY and PF see: Branko Petranović, "Narodni front u političkom sistemu Jugosavije 1945-1949”, Istraživanja 8/1979, 337-342; Branko Petranović, "Osnivački kongres Narodnog fronta Jugoslavije", Časopis za suvremenu povijest 1/1980, 9-12; Nevenka Troha, "Sobivanje ali soodvisnost Komunistične partije Slovenije in Osvobodilne fronte Slovenije (1945-1953)", Prispevki za novejšo zgodovino 1/2011, 241-270.

5 For a comprehensive analysis of the scholarly works on the Yugoslav PF, until 1980 see: Katarina Spehnjak, "Orijentacioni pregled i analiza izvora i literature o SSRNJ 1945-1978", Časopis za suvremenu povijest $3 / 1980,109-129$. There is a number of studies from the period following 1980 that are worth emphasizing: Katarina Spehnjak, "Narodni front Jugoslavije : (SSRNJ - razvoj, programnsko-teorijske osnove i procesi u društvenoj praksi 1945-1983)", Povijesni prilozi: zbornik radova, 3/1984, 1182; Драгољуб Петровић, Народни Фронту Србији и путу једнопартијски систем 1941-1945, (Београд: Институт за новију историју Србије, 1997). On the activity of Blagoje Nešković at the position of the jead of the PF Executive Committee see: Ена Мирковић, "Благоје Нешковић (1907-1984). Политичка биографија“, (Doctoral Thesis, University of Belgrade, Faculty of Philosophy, 2016), accessed 1. 10. 2018, http://nardus.mpn.gov.rs/bitstream/handle/123456789/7872/Disertacija.pd$\mathrm{f}$ ? sequence $=1$ \&isAllowed $=\mathrm{y}$

6 Јелена Попов, Народни фронт у Војводини, (Нови Сад: Филозофски факултет, 1986).

7 Branko Petranović, Političke i pravne prilike za vreme privremene vlade DFJ, (Beograd: Institut društvenih nauka, 1969), 173-205; Branko Petranović, Politička i ekonomska osnova narodne vlasti u Jugoslaviji za vreme obnove, (Beograd: Institut za savremenu 
In implementing the politics of the "socialist reconstruction of rural areas" the PF played an even more important role than the CPY, at least in the first three or four years that followed the end of WWII. Alongside numerous cultural activities, aimed at en masse education and emancipation of the peasantry, ${ }^{8}$ the PF organizations were mainly in charge of popularizing and, in some cases, executing the agrarian policy measures. Through the $\mathrm{PF}$, the implementation of the socialist development in rural areas also included and engaged men and women who were not CPY members but who were also supposed to be informed about and in line with the "course" set by the CPY-dominated government. ${ }^{9}$ Thus, the various activities of the $\mathrm{PF}$ actively contributed to "preparing the most numerous and primitive part of the population - the small and middle peasants - for socialism." ${ }^{10}$ In some cases the regional (republican) PF organizations issued more or less elaborated programs and curricula for the courses, defining topics and related literature. The topics were both general ("CPY Program", "CPY in the struggle for democracy, national equality and rights of the working people" etc.), and specific, related to the issues relevant for the peasantry ("Development of the socialist sector in agriculture", "The struggle of the CPY against the capitalist elements in the rural areas" etc. ${ }^{11}$

During the first three years of socialist development in Yugoslavia, the CPY was somehow in a clandestine position, particularly in the rural areas: the PF functioned as the transmitter of Party policies. This situation changed in 1948/49, when the Party stepped forward, challenged by accusations from the Cominform of acting, allegedly, almost as an illegal organization, without any connection to the masses. Nevertheless, despite the level of its visibility, the Party effectively controlled the PF or-

istoriju, 1969), 82-126; Petranović, "Narodni front u političkom sistemu Jugoslavije”, 309-399.

8 See: Ljubodrag Dimić, Agitprop kultura. Agitpropovska faza kulturne politike u Srbiji 1945-1952, (Beograd: Rad, 1988), 86-95; Попов, Народни фронт у Војводини, 253-257; Dobrivojević, Selo i grad, 270-294.

9 Archve of Yugoslavia (AJ), Fond 507, Savez komunista Jugoslavija (League of Communists of Yugoslavia - SKJ), Komisija za selo, - XV 1/4, Zapisnik sa prvog sastanka IV grupe aktiva pri Komisiji za selo CK KPJ održan 3. VI. 1949. g.

10 Мило Јовићевић, Улога и задаци Народног фронта на селу, (Београд: Народни фронт Југославије, 1949), 3. (The author was the secretary of the Executive committee of PF).

11 Програм курсева и кружока за организације Народног фронта у граду и селу, (Београд: Земаљски одбор народног фронта Србије, 1949); Програм идеолошко-васпитних курсева и кружока за организације Народног фронта на селу, (Сарајево: Комисија за идеолошко-васпитни рад Главног одбора народног фронта Босне и Херцеговине, 1949). 
ganizations, with the communists predominantly occupying the leading positions within the structure. ${ }^{12}$

\section{Political Definition of Aims (1945-1948)}

In his speech at the First Congress of the PF in 1945, Josip Broz Tito, who was head of the organization and president of the government, defined the tasks of the PF in the domain of agriculture: to "sow the fields," "increase production," and make "ultimate efforts" in order to prevent a famine. ${ }^{13} \mathrm{He}$ also recognized the contribution of the PF organizations in the postwar reconstruction of rural areas, without overemphasizing his CPY. ${ }^{14}$ These tasks had been already taken by the PF, which was particularly important in Vojvodina, in the first months after the liberation, during the most exhaustive "agricultural campaign" in 1944/45. ${ }^{15}$

Regarding rural policy, Tito only drew the main outline of the image that was elaborated in the PF Program, adopted by the First Congress in 1945. The main features of the Program were: efforts toward advancing the cooperative movement among farmers; the agrarian (land) reform, whose task was to provide land to poor and landless peasants, "those who toil it"; writing off the debts peasants made before and during WWII; progressive taxation that was supposed to affect rich peasants; networking between rural (producing) and urban (distributive) cooperatives and the state sector; effective assistance in rebuilding households; a general advancement of the overall conditions of the peasantry (health, cultural life, education etc. ${ }^{16}$

Blagoje Nešković, one of the leading Serbian communists and and one of the leading figures in the PF, was more explicit concerning the function of that organization: by accepting non-communist political personalities in the PF the communists could use their authority in order to gain the support of the (primarily) middle peasants. On the other hand, the communists couldn't allow those non-communist politicians to profit from the weaknesses of the Party and from the fragile relations with the peas-

12 AJ, Fond Socijalistički savez radnog naroda Jugoslavije (Socialist Union of Working People of Yugoslavia - SSRNJ), f. 19-58, Izveštaj o radu Narodnog fronta, 403.

13 “Говор предсједника Народног Фронта Југославије Маршала Јосипа Броза Тита", Први Конгрес Народног Фронта Југославије, (s. l., s. n., 1945), 59.

14 AJ, SSRNJ, f. 1-6, Govor na Drugom kongresu NF.

15 Попов, Народни фронт у Војводини, 88-90, 99-100.

16 “Основна програмска начела Народног Фронта Југославије”, Први Конгрес, 68, 71-2. 
antry. Thus, according to Nešković, the non-communist political leaders in the PF were kept under control. ${ }^{17}$

During the Second Congress of the PF in 1947, Sreten Žujović, than secretary of the organization, put particular emphasis on the importance of the PF within the Yugoslav system, since the PF was designed as an "ideal form" that embodied the "alliance between workers and peasants" - the revolutionary Leninist ideal in the context of the triumphant socialist revolution in a predominantly agrarian society. The "assistance to the village" was supposed to become one of the regular forms of the PFs' activities, in order to increase the participation of the PF organizations in post war rebuilding and transformation of agricultural areas. ${ }^{18}$

On the other hand the PF was significantly involved in the effectuation of the compulsory collection of the surpluses of agricultural products ("obavezni otkup poljoprivrednih proizvoda"). The engagement of the PF organizations in propagating the importance of this demanding endeavour brought in some parts of the country significant results - for instance in Zemunski srez in $1946 .{ }^{19}$ The effectuation of the compulsory collection of the surpluses, according to S. Žujović, had been constantly endangered by the "sabotage of the enemies of the people, opposed to the interests of the state and the peasants." However, Žujović asserted that the mentioned compulsory delivery was particularly successful in the areas with firmly established and active PF organizations. With this activity, the PF contributed to the class struggle in the rural areas against the "capitalist elements" among the peasants ("kulaks"). In carrying out their counter-revolutionary activity, the "capitalist elements" had counted on the "former political backwardness of the peasants, losing from sight the powerful influence of the National Front," which mobilized the masses, "strengthening the class alliance of the working class with other working masses," "honing the blade of that alliance against the capitalist elements in the rural regions." ${ }^{20}$ In this sense, it was particularly important to engage the PF in preventing the rich peasants from obtaining leading positions in the

17 Seе: Мирковић, op. cit., 265.

18 AJ, SSRNJ, f. 1-6, Stenografske beleške Drugog kongresa Narodnog fronta Jugoslavije održanog na dane 26, 27 i 28 septembra 1947 godine u Beogradu (Speech of S. Žujović). N. b.: Whenever I find that it is important to indicate the person I am quoting in the text or to clarify the type or the subject of the document (if it has no original title) I put that information in the brackets.

19 Попов, Народни фронт у Војводини, 126.

20 AJ, SSRNJ, f. 19-57, Sastanak Izvršnog odbora Narodnog fronta Jugoslavije, održan 23 januara 1950 godine u Beogradu, (Discussion of E. Kardelj), 73. 
rural cooperatives, which occasionally happened. ${ }^{21}$ That is why not only the Party (which had its' own strict rules for membership), but the PF organizations too attracted almost exclusively poor and middle peasants. ${ }^{22}$

Among the first activities that the PF was engaged in was the ambitious building of the so-called "cooperative centers" ("zadružni domovi") all over Yugoslavia. This project was initiated by Tito himself in 1947, but some of his close associates and comrades were not enthusiastic about the idea. One of them was Sreten Žujović, whose opposition to the project was inspired by the conceptual differences regarding investment priorities. He could not openly challenge Tito's initiative, but he tried to narrow its scope, which led to an interesting debate among the members of the PF leadership. This closed session actually revealed two major issues and the discussion about Tito's initiative was only the spark. The first thing was the dissatisfaction of Secretary Žujović with the achievements of the local PF "working brigades." These were supposed to accomplish Tito's project but, according to Žujović, up to that moment, were actually fulfilling their tasks "carelessly" and were not capable of such an ambitious endeavor. The second issue, even more important, is the first glimpse of Žujović's dissonant tone concerning the general course of the government's peasant and rural policy. ${ }^{23}$

In his speech at the Fifth CPY Congress in July of 1948, Edvard Kardelj praised the PF's organizational potential and network: by virtue of this organizational structure, the PF more effectively "masters occasional hesitations in implementing the Party line, particularly in the rural areas," Kardelj explained. ${ }^{24}$ These "hesitations" were a clear reference to the resistance that the government was faced with in the rural areas and that is why the broader political consensus within the PF still played an important role in damping the conflict between the communists and the non-communists. On the same occasion, Petar Stambolic (at that time minister for agriculture in the federal government) noticed that the PF did not engage all its potentials "in the activities concerning the develop-

21 AJ, SSRNJ, f. 31-92, Narodni front i zadrugarstvo, 151.

22 Bokovoy, op. cit., 90.

23 AJ, SSRNJ, f. 19-57, Stenografske beleške. Sednica proširenog Izvršnog odbora Narodnog fronta Jugoslavije - održana 29. novembra 1947 god, (Discussion ofS.Žujović), 8. - Along with Andrija Hebrang, Žujović was another leading political figure that sided with the accusers from Informbiro in 1948.

24 Едвард Кардељ, “Комунистичка Партија Југославије у борби за нову Југославију, за народну власт и социјализам”, V конгрес Комунистичке Партије Југославије 21-28. јул 1948. Стенографске белешке, (Београд: Култура, 1949), 576. 
ment of the cooperatives and agriculture,"25 and Blagoje Nešković, chairman of the PF Secretariat, shared his views regarding this "great historical task" of the PF in terms of the socialist reconstruction of the rural areas. ${ }^{26}$

\section{Forms of PF Activity and Their Coordination}

The PF organizations worked actively on promoting the peasant cooperatives including the founding of the cooperative economies, livestock farms, cooperative vineyards, cellars, orchards, machine stations, veterinary pharmacies; organizing lectures and courses for agricultural producers, and visits of the individual farmers to the successful economies of the socialist sector; sending agronomists to cooperatives; sending the press and the various literature to cooperatives. Of particular importance was the organized assistance of the trade unions from the towns to the cooperatives concerning a whole variety of needs, beginning from technical assistance, to medical treatment. This was a means of forging an alliance between the working class and the peasants. ${ }^{27}$

During 1948, the construction of cooperative centers was particularly intensive, followed by a somewhat stronger engagement of the PF in the rural regions, mostly in organizing agricultural activity, but political activity in the countryside wasn't really very dynamic. However, it was this very countryside where this political activity of the PF was needed the most. In addition, according to Blagoje Neskovic, this political activity was nothing but a class struggle, which the PF members did not always understand. This activity was particularly important in the countryside because the abundant rural population was outside the Party membership, and thus it was possible to obtain them for and organize in a systematized structure of socialist order through the $\mathrm{PF}^{28}$

Although the transition to a planned economy in 1947 initiated the formation of a whole range of specialized sections within the structure of the PF, including the section for agriculture, this particular one did not develop any significant activity. The real intensification of PF activi-

25 “Резолуција V Конгреса КПЈ о основним наредним задацима организација КПј”, Vконгрес Комунистичке Партије Југославије, 792.

26 Благоје Нешковић, "Народни фронт и задружне организације”, Зборник материјала о задругарству ФНР), (Београд: Комитет за задругарство владе ФНРЈ, 1948), 58.

27 Јовићевић, op. cit., 30.

28 AJ, SSRNJ, f. 16, Organizacioni problemi Narodnog fronta, (Report on the extended Plenum of the Federal Committee of PFY, 28.11. 1948). 
ties in the rural regions came after the split with the USSR in 1948 and, in particular, after the Second Plenary Session of the Central Committee of the CPY, in February of 1949, which was almost entirely dedicated to the issues of agricultural policy. The end of 1948 saw - among other specialized bodies - the creation of the Agricultural Commission (attached to the Federal Committee of the PF and headed by Mijalko Todorović) and the Administration for the Construction of Cooperative Centers, headed by Nikola Kovačević. This structure was reorganized once again at the end of 1949, by setting up the Commission for Agriculture and Cooperatives, which, in 1950, became the Commission for Agriculture and Reforestation. In 1950 the Commission for the Competition of the Peasant Working Cooperatives was also organized. These commissions were established at all the PF organizational levels.

The PF's Commission for Agriculture and Reforestation embodied the widest scope of competences: coordination of activities with the Ministry of Agriculture; campaigning for the implementation of measures promulgated by the Ministry in order to overcome "conservatism in agriculture and cattle breeding"; organization of field work volunteer brigades; propagating the benefits of working in cooperatives and advanced methods of agricultural production. By organizing public lectures the commission activists should have contributed to the adoption of advanced agricultural methods, in order to increase production; by organizing visits to advanced state-owned farms, the PF commissions encouraged the transfer of positive experiences between different regions and sectors of production. Svetozar Vukmanović Tempo pointed out that the task of this PF commission was also the struggle for the advancement of individual farmer households, expecting that this attitude would be met with approval "in every village," recognizing the interest of both the farmers and the state.

The Administration for Cooperative Centers was in charge of supervising and coordinating the completion of this construction, which was financed by the state, and also urging the rural communities to raise funds on their own for this purpose, in cases where no state investments were planned. As early as 1950, this administration was attached to the PF's Commission for Agriculture. ${ }^{29}$

29 AJ, SSRNJ, f. 16-1, Stenografski zapisnik sednice Saveznog odbora Narodnog fronta Jugoslavije održane na dan 19. juna 1948, (Report of P. Stambolić), 3; AJ, SSRNJ, f. 20 64, Zapisnik sednice Sekretarijata Narodnog fronta Jugoslavije od 16 decembra 1948 god. 6 januara 1949 godine, 1; Ibid., Sastanak Sekretarijata Saveznog odbora Narodnog fronta Jugoslavije, 6 januar 1949 godine, 34-39, 46; Ibid., Zapisnik sa sastanka rukovodilaca komisija i uprava Saveznog odbora Narodnog fronta Jugoslavije, održa- 


\section{New Impulse to PF Activities After 1948 IB Resolution}

As it is well known and has already discussed in many scholarly works, the 1948 IB Resolution pushed the Yugoslav communists toward more intensive and more Soviet-style measures with regard to rural areas. ${ }^{30}$ Although the Party itself took a more active role in the field, the PF still remained an important agent, with a developed network and practices. But the role of the PF organizations remained primarily ideological, aiming at affirming the new political consciousness. ${ }^{31}$ Petar Stambolić praised past achievements in that domain, emphasizing that the PF had decisively contributed to the affirmation of the alliance between the working class and the peasantry and to the acceptance of socialist policies among the peasants. ${ }^{32}$

The new tone of the sharpened class struggle was introduced in the revised Program of the PF, which openly insisted that "working peasants, backed by the state of the working people, should gather in working cooperatives, and particularly by creating common property in land and over the means of production, strive toward a fundamental change of their lives" and wage a struggle "against rural capitalists and speculators, who are still trying to manipulate them." Victory in that struggle should put an end to the exploitation of the individual by another, enforce the al-

nog 15. januara 1949 godine, 54-55; Ibid., Sastanak rukovodilaca komisija i uprava Saveznog odbora Narodnog fronta Jugoslavije, 15-I-1949 godine; Ibid., Odluka Sekretarijata Saveznog odbora Narodnog fronta Jugoslavije o osnovnim zadacima pomoćnih tela pri Saveznom odboru, 77; Ibid., Sastanak Sekretarijata Izvršnog odbora Narodnog fronta Jugoslavije održan 23. septembra 1949 g., 583-584; Ibid., Zapisnik sednice Izvršnog odbora Narodnog fronta Jugoslavije održane 29 juna 1950 godine, 708-709; Ibid., Rad komisija Izvršnog odbora NFJ, 718-719; AJ, SSRNJ, f. 31-91, Zapisnik sa sastanka Komisije za poljoprivredu održanog na dan 23. III 1949 g, 2; Ibid., Plenarni sastanak Komisije za poljoprivredu i zadrugarstvo održan 10-II-1950, 47; AJ, SSRNJ, f. 31-92, Osnovni zadaci Komisije za poljoprivredu, 129.

30 Попов, Народни фронт у Војводини, 299-300; Гудац, ор. cit., 79-88; Bokovoy, ор. cit., 86-100; Z. Čepić, "Spor z Informbirojem in jugoslovanska kmetijska politika”, Jugoslavija v hladni vojni: zbornik z Znanstvenega posveta Jugoslavija v hladni vojni, (Ljubljana: Inštitut za novejšo zgodovino, 2004), 319-338; Милошевић, op. cit., 198208.

31 “Закључци пленума Комисије за идеолошко-васпитни рад Савезног одбора НФJ”, Народни фронт 3/1949, 54; “Закључци Пленарног састанка Комисије за организациона питања Савезног одбора НФЈ". Народни фронт 5/1949, 28; „Закључци Пленума за идеолошко-васпитни рад”, Народни фронт 5/1949, 32; М. Милићевић, "Нове мерезајачањеСРЗ и улога Фронтау њиховом спровођењу”, Народни фронт 8-9/1951, 11.

32 AJ, SSRNJ, f. 2-7, Tok rada Trećeg kongresa Narodnog fronta Jugoslavije, (P. Stambolićs' discussion at the Third Congress of PF). 
liance between workers and peasants, and eliminate any threat of misery and decay. ${ }^{33}$

When it comes to the question of the attitude that the PF organizations took toward those individual peasants who did not want to join working cooperatives, the minister of agriculture and head of the PF Commission explained: "The basic means that the Popular Front should apply in performing the tasks in the private sector is political mobilization of all members of the PF... in order to elaborate the annual plans specified for a particular committee by the state authorities; to discover each segment of the arable land; to deploy these plans by individualizing them for each producer; to correct the mistakes made by agricultural authorities that often consist in incorrect scheduling of tasks, which causes harmful political consequences and failure of the plan itself." In addition, having done all the above mentioned, the PF organizations were expected to "put pressure to bear on individual peasants to sow". ${ }^{34}$

The scramble to set up the peasants' working cooperatives (PWC) after 1949 made the role of the Popular Front in this domain particularly important. Dobrosav Tomašević, the chairman of the Federal Cooperative Association, said at the Third Congress of the PF in 1949 that it was the PF that substantially contributed to the transformation of the individual farmer into a collective farmer, a "persistent builder of socialism." ${ }^{35} \mathrm{At}$ the Third Congress of the PF, Tito praised the activity of its organizations in advocating and supporting collectivization, which became "their socialist commitment." ${ }^{36}$

From 1949, when the Party intensified its engagement in the rural areas, NF organizations became the source of the new Party members. Namely, the CPY was eager to either enforce the already existing organizations, or form new ones in rural areas where they did not exist. ${ }^{37}$ Following the Party line, the PF confirmed and strengthened its commitment to the class struggle, more openly confirming itself as a primarily politi-

33 “Програмска декларација", Трећи конгрес Народног фронта Југославије, (Београд: Борба, 1949), 95.

34 AJ, SSRNJ, k. 31-91, Plenarni sastanak Komisije za poljoprivredu i zadrugarstvo održan 10-II-1950, 37.

35 AJ, SSRNJ, 2-7, Tok rada Trećeg kongresa Narodnog fronta Jugoslavije, (The speech of D. Tomašević).

36 Јосип Броз Тито, “Реферат на Трећем конгресу Народног фронта Југославије”, Говори и чланци VII, 201.

37 AJ, CKSKJ, XV 1/4, Zapisnik sa prvog sastanka IV grupe aktiva pri Komisije za selo CK KPJ održan 3. VI. 1949. g. 
cal agent of the socialist revolution. ${ }^{38}$ This was clearly underlined at the Third Congress of the PF, in April of 1949, when the Program Declaration concluded that the PF would "steadily fight for victory of socialism in the agrarian communities," that it would prevent rich peasants and speculators from spreading their influence in the villages, and that it would safely and effectively clear the ranks of the organization from the mentioned elements, by persistently struggling for the socialist transformation of the village ${ }^{39}$ Within the given context, as Mijalko Todorović once explained, "whenever the authorities enforce punishment, the Front is obliged to explain the reasons for such an action by the government." ${ }^{40}$

\section{Forms of PF Activities in Rural Areas After 1949}

The large-scale establishment of peasant working cooperatives in 1949 and 1950 caused an overlapping of competences between cooperative assemblies, on one side, and conferences of PF organizations on the other. Under the given circumstances, it was underlined that regarding political issues and interpretation of the general line of socialist development, the role of the PF remained irreplaceable. The PF organizations played the role of the "political base" of cooperatives, fulfilling the task of "political guidance," but they were not expected at all to take over the management of the cooperatives. Their tasks were the following: assistance in fulfilling the plan of production and investment; construction of cooperative centers; assistance to the economies of agricultural cooperatives; political efforts on consolidation, expansion and establishment of numerous peasant working cooperatives; planning of cultural activities in peasant working cooperatives. In addition, due to various examples of sectarianism and pressure on non-collectivized peasants, in order to prevent undesirable divisions or even conflicts among individual peasants and peasants organized in cooperatives, $\mathrm{PF}$ organizations were expected to coordinate ideological and political sessions with individual and collectivized peasants jointly taking part in them. ${ }^{41}$

38 Petranović, "Narodni front u političkom sistemu Jugoslavije”, 387; AJ, SSRNJ, f. 2-7, Stenografske beleške sa Trećeg kongresa NFJ, (The speech of Stevan Doronjski).

39 AJ, SSRNJ, f. 2-7, (Project of the declaration of the PF).

40 AJ, SSRNJ, f. 20-64, Sednica Sekretarijata Izvršnog odbora NF Jugoslavije (23. X. 1950), 74.

41 AJ, SSRNJ, f. 30-64, Sastanak Sekretarijata Saveznog odbora Narodnog fronta Jugoslavije održan 4 aprila 1951 g., 110; М. Радић, “Организације народног фронта у мјестима са сељачким радним задругама”, Народни фронт 2/1951, 13-15; АJ, 
The PF was also promoting the advantages of living and working in cooperatives, which sometimes was followed by organizing excursions of farmers from regions without developed cooperative life to Vojvodina or other parts of the country where the cooperatives were the most successful. ${ }^{42}$ The authorities especially focused the ideological and organizational aspects of the PF activities concerning cooperatives, but in the broadest meaning. Thus, for instance, it was through the PF that children from towns were being sent to peasant cooperatives for the summer holidays to take part in household work and to experience the lifestyle of their parents' "allies" from the countryside. ${ }^{43}$

Apart from what has been already mentioned, the PF organizations were required to become involved in sowing campaigns and in other field works in all three sectors (private, state and cooperative). Activity in the private sector was envisioned primarily for the so called "vulnerable groups" that included widows, war invalids, disabled persons, or individual farmers who could not work the land for any number of reasons. Furthermore, the PF organizations were required to participate in local meliorations; in organizing the fight against various pests; to participate in estimating surpluses of agricultural products to be purchased by the state ("otkup"); to propagate the regular payment of taxes; to raise new breeds of domestic animals and sow new sorts of crops and other plants (especially the cultivation of industrial plants); to petition for the appli-

SSRNJ, f. 20-64, Sastanak sa sekretarima republičkih sekretarijata Narodnog fronta održan 5 aprila 1951 godine, 59; AJ, SSRNJ, f. 19-58, Metodologija planiranja privredne i zdravstvene delatnosti Narodnog fronta Jugoslavije, 253; J. Хрнчевић, “О идеолошко-васпитном раду Народног фронта", Седница Извршног одбора Народног фронта Југославије, (Београд, 1950), 19.

42 АЈ, ЦК СКЈ, XV-1/2.

43 Ј. Б. Тито, “Политички извјештај”, Трећи конгрес Народног фронта Југославије, (Београд, 1949), 7; Љ. Арсов, "Привредна делатност народног фронта Југославије”, Седница Извршног одбора Народног фронта, 23-24; К. Попивода, “Извештај о раду народног фронта Југославије”, ibid., 97; Јовићевић, op. cit., 14; В. Жунић, "Искуства организације народног фронта среза Тимочког у развијању локалне делатности”, Народни фронт 2/1949, 45; М. Ковићевић, “Основни резултати рада Народног фронта у првој половини 1949 године”, Народни фронт 3/1949, 4; Б. J. “Резултати изградње задружних домова”, Народни фронт 5/1949, 43-44; Д. Бајалица, "Развијање такмичења сељачких радних задруга нов задатак Народног фронта”, Народни фронт 5/1949, 1-7; А. Ранков, “Летовање пионира у сељачким радним задругама", Народни фронт 2/1949, 47-50; Љ. Арсов, "Привредна делатност Народног фронта Југославије у 1949 години”, Народни фронт 1-2/1950, 32-33; М. Милићевић, “О раду основне фронтовске организације на селу", Партиска изградња 7/1950, 35-52. 
cation of advanced agro-technical measures in agriculture; to persuade the farmers not to leave the fields uncultivated. ${ }^{4}$

Particularly important was the agitation of the PF organizations on the occasion of various censuses and data-collecting related to agriculture, which was of the highest importance for the planned agriculture. In addition to these activities, the local PF sections also campaigned against the slaughter of livestock (this deliberate slaughtering was a tactic to avoid conforming to the economic plan), against hiding animals from the eyes of the census commissions, against moving entire herds of livestock from one village to another, and against similar tactics aimed at outsmarting the authorities. In all these issues, the PF's political and organizational support and decisive activity were required because, as Svetozar Vukmanović Tempo argued, "if we do not get tough, nothing will be done." ${ }^{45}$ In the domain of propaganda, the activity of the PF in the villages was carried out through verbal agitation (lectures, reading groups), radio (specialized radio broadcasts), documentaries, but also through local exhibitions and fairs, excursions, and through printing and distributing of brochures, posters, and leaflets. ${ }^{46}$

When the PF was taking part in agricultural works, it was organized through a system of voluntary work brigades, although, in fact, it was forced labor in many cases. However, meliorations, building of coopera-

44 Попов, Народни фронт у Војводини, 295-299; М. Митровић, “Активности комуниста пожаревачког краја у органима народне власти и масовним организацијама", Изгубљене илузије, (Београд: Институт за новију историју Србије, 1997), 283-287; Први конгрес ЈНОФ, (Београд, 1945); С. Жујовић, “Извештај о раду Народног Фронта Југославије”, 21; AJ, SSRNJ, f. 19-61, Zemaljskom odboru Narodnog fronta, (Letter from the Secretariat of the PFs' Executive Committee of the republican committees about the taxation of the peasants), 572; Б. Нешковић, "Извештај о раду Народног фронта", Трећи конгрес Народног фронта Југославије, 74-88; “Резолуција о текућим задацима Народног фронта Југославије”, Народни фронт 1-2/1950, 48; Попивода, “Извештај о раду народног фронта Југославије”, 102103; AJ, SSRNJ, f. 2-7, (B. Neškovićs' report at the Third Congress of the PF); Ibid., (Spech of L. Koliševski at the Third Congress of the PF); AJ, SSRNJ, f. 19-57, Sastanak Izvršnog odbora Narodnog fronta Jugoslavije, održan 23 januara 1950 godine u Beogradu, (Discussion of Rodoljub Čolaković), 36; AJ, SSRNJ, f. 19-58, Metodologija planiranja privredne i zdravstvene delatnosti Narodnog fronta Jugoslavije, 253-257; AJ, SSRNJ, f. 31-91, Plenarni sastanak Komisije za poljoprivredu i zadrugarstvo održan 10-II-1950, 36-37; Ibid., Zapisnik sa sastanka Komisije za poljoprivredu i zadrugarstvo održanog na dan 21 aprila 1950 godine, 15; Ibid., (Conclusions from the plenary session of the PFs' Commission for agriculture), 90-91.

45 AJ, SSRNJ, f. 20-64, Sastanak Sekretarijata Saveznog odbora Narodnog fronta Jugoslavije, 6 januar 1949 godine, 49.

46 AJ, SSRNJ, f. 31-92, Forme agitacije, 126. 
tive infrastructure and working in the fields were not the only type of the activity of these brigades: even more frequently they were sent to assist in some industrial endeavor, forging, from their side, an alliance between workers and peasants. ${ }^{47}$

The role of the NF was particularly important in organizing competitions among cooperatives ("zadružno takmičenje"). The competitive enthusiasm was intensified in this domain only as of 1950, when the number of cooperatives increased and they themselves were consolidated. The initiative for organizing the competition came from the Federal Cooperative Association, but it was taken over by the PF, which had larger capacities at its disposal. A specialized Commission for Cooperative Competitions was set up at the Federal Committee of the PF. Similar commissions were formed within the structure of the lower PF organizations. ${ }^{48}$

\section{Shortcomings in the Activities of PF Organizations}

The work of the PF organizations in urban environments suffered from the very beginning from organizational, theoretical and practical weaknesses. The PF was primarily engaged in implementing certain concrete activities ("mere practicism"), but also, albeit to a lesser degree, on the ideological and the political aspect, in other words, on explaining the very essence of the transformation taking place in the rural areas. According to Jovan Veselinov, the leading communist from Vojvodina and a member of the CPY's Central Committee, agricultural producers eventually "became accustomed to holding conferences just to receive orders, not to hear lectures or clarify issues" (J. Veselinov). This was particularly true in the case of the basic PF organizations, although it was the most detrimental for them. The optimistic view expressed during a meeting in 1950 by Blagoje Nešković that the PF organizations in the rural areas eventually stabilized their structure and improved their methods, was refuted by

47 AJ, SSRNJ, f. 16, Б. Нешковић, “Организациони проблеми Народног фронта”, 210; Јовићевић, ор. cit., 10, 22-23.

48 AJ, SSRNJ, f. 19-61, (Letter of the Ministry for agriculture), 569; AJ, SSRNJ, f. 20-64, Zapisnik proširene sednice Izvršnog odbora Narodnog fronta Jugoslavije, održane 7 juna 1949, 478; Бајалица, “Развијање такмичења сељачких радних задруга”, 1-7; “Закључци пленума за такмичење сељачких радних задруга”, Народни фронт 3/1950, 55-57; С. Шехагић, “О неким искуствима из такмичења сељачких радних задруга”, Задруга, бр. 62, 27. април 1950, 4; “Закључци пленума Комисије за пољопривреду и шумарство", Народни фронт 3/1950; AJ, SSRNJ, f. 20-64, Zaključci Sekretarijata Izvršnog odbora Narodnog fronta Jugoslavije sa sednice od 1 avgusta 1950 godine, 755 . 
Rodoljub Čolaković, who argued that the work of the PF in the agricultural environment (at least in Bosnia) was so poor that, he claimed, this organization had functioned better during the war.

The main problem was the lack of continuity and stability, the actions were being undertaken "in a campaign manner," shifting from one to another without any substantial results. There was no regularity in holding meetings and conferences in the basic organizations and the most relevant issues of the day for a particular rural community would pass without any activity, not to mention getting no initiative on behalf of the PF organizations. From the point of view of the Party leadership, this was a case of intolerable negligence of the class struggle and carelessness in the endeavor of the socialist transformation of rural areas and of society as a whole. Furthermore, the conferences of the PF organizations were occasionally transformed into a grandstand of the rich farmers who, defending their own interests, agitated against socialism. This was particularly encouraged after the IB Resolution, since under the given circumstances it was comfortable to opportunistically argue that the CPY had been condemned even by the Soviets.

One of the main characteristics of PF activities was an uncompromising insistence on establishing the highest type of cooperative organizations - peasant work cooperatives - even within the background and under the conditions that were, least of all - unfavorable for this endeavor, while at the same time the other types of cooperatives were neglected, although they needed support in various aspects (organization of work, accounting, cultural activities etc.)

The individual peasants were too often discriminated, maltreated and oppressed, in spite of the fact that the leadership of the PF insisted on the ideological and instructive activities, rather than physical or other forms of coercion. This "sectarian attitude" toward individual peasants inspired, time and again, numerous instructive orders, articles and speeches that emphasized the importance of ideological education of both individual and collectivized peasants. The small and middle peasants on one side and the cooperatives on the other, owed each other mutual assistance, which was mainly the responsibility of the cooperatives. On occasion, the PF organizations took over the whole taxation procedures, or work on the preparation of the compulsory collection of agricultural surpluses ("otkup"), both being the competence of the state authorities. The attitude toward national minorities also suffered from this sectarian approach, manifesting itself in various forms of discrimination. For instance, 
the members of the Turkish population in Macedonia were forced to enter the worker cooperatives under the pressure of the slogan "either in a cooperative, or in Turkey," which was launched by PF activists. ${ }^{49}$

The voluntary work brigades were, in fact, in many cases a source of forced labor and even the police were deployed occasionally in order to force the peasants to take part in the public or other works. Edvard Kardelj was the first who discussed this issue and put forth the idea that the working brigades should be sent to work only within their local communities. On the other hand, those who were true volunteers and who achieved considerable results in their work were quite often given privileges, particularly in terms of food supply or some other aspects of everyday life, which was also against the principal idea that their reward was supposed to be moral, not material. ${ }^{50}$

49 Јовићевић, op. cit., 34; Љ. Вељковић, “Како и у чему помоћи новооснованим сељачким радним задругама”, Народно задругарство 1/1949, 29; “Закључци пленума комисије за идеолошко-васпитни рад", 54; AJ, SSRNJ, f. 19, Zapisnik sa sastanka sa pojedinim drugovima iz ekipa koje su obilazile frontovske organizacije po republikama, 14; AJ, SSRNJ, f. 16-13, Stenografski zapisnik sednice Saveznog odbora Narodnog fronta Jugoslavije održane na dan 19. juna 1948, (Discussion of V. Vlahović); AJ, 142-16-69, Stenografske beleške sa zasedanja proširenog Plenuma Narodnog fronta Jugoslavije, 27. novembra 1948; AJ, 142-20-64, l. 425-426, Zapisnik proširene sednice Izvršnog odbora Narodnog fronta Jugoslavije, održane 7 juna 1949; AJ, 142-31-91, l. 7, Zapisnik sa sastanka Komisije za poljoprivredu i zadrugarstvo, 6. I. 1950; AJ, 142-20-64, l. 780-781, Sednica Sekretarijata Izvršnog odbora NF Jugoslavije (23. X. 1950); AJ, 142-31-93, Sastanak Uprave za poljoprivredu Narodnog fronta održan 10 oktobra 1950 godine; AJ, 142-19-57, Sednica Izvršnog odbora Narodnog fronta Jugoslavije, 28 septembra 1951 godine; AJ, 142-30-64, l. 111, 112, Sastanak Sekretarijata Saveznog odbora Narodnog fronta Jugoslavije održan 4 aprila 1951 g.; AJ, 142-20-64, l. 388, Agitaciono politički i ideološki rad; AJ, 142-16-349, Sastanak pretstavnika glavnih odbora i Saveznog odbora Narodnog fronta Jugoslavije, 28. mart 1952 godine.

50 Попов, Народни фронту Војводини, 298; Olivera Milosavljević, Država i samoupravljanje: 1949-1956, (Doctoral Thesis, University of Belgrade, Faculty of Philosophy, 1987); AJ, SSRNJ, f. 19-57, Zapisnik sa sastanka sa pojedinim drugovima iz ekipa koje su obilazile frontovske organizacije po republikama, 13; AJ, SSRNJ, f. 16, B. Nešković, "Organizacioni problemi Narodnog fronta"; AJ, SSRNJ, f. 16, (Stenographic minutes from the extended Plenum of the Federal Committee of PFY, 27. 11.1948), 107; AJ, SSRNJ, f. 20-64, Zapisnik proširene sednice Izvršnog odbora Narodnog fronta Jugoslavije, održane 7 juna 1949, 425; AJ, SSRNJ, f. 19-57, Sastanak Izvršnog odbora Narodnog fronta Jugoslavije, održan 23 januara 1950 godine u Beogradu, (Discussion of E. Kardelj), 35. - The instructive documents mention only a small honourable flags and the honourable title "shock brigade" ("udarna brigada") as a rewards for the achieved results. See: Упутство о организацији посебних бригада Народног фронта и Упутство о опремању, транспортовању и смјештају посебних бригада народног фронта, (Сарајево: Државна штампарија, 1949), art. V, 7. 
Since the beginning of the 1950s, the activities of the PF in the urban communities were waning. However, this was no longer an aftermath of organizational shortcomings but of the fact that the intensive engagement of this organization had become redundant under new circumstances, characterized by a complete takeover by the Party. Immediately after the war, a struggle was taking place between "old and new" and the apparatus of the new socialist state was still emerging, thus the PF played a role analogous to the Party's. "Today, that no longer makes any sense," PF Secretary Blagoje Nešković remarked. The PF needed a restructuring. Basic PF organizations in the villages had lost their significance and even their regular convocation was no longer required. ${ }^{51}$ The PF needed a new impulse and that impulse came with the reorganization of the NF into the Socialist Alliance of the Working People of Yugoslavia (Socijalistički savez radnog naroda Jugoslavije - SSRNJ) in 1953, but the activity of this organization falls into a period that is outside the scope of this paper.

\section{Conclusion}

The rural environment in post-WWII Yugoslav has been the main source of human and material forces for the reconstruction of the country and the simultaneous socialist transformation, that undeniably achieved considerable results. The role of the PF orgaizations under uncertain political and economic conditions was particularly important. They served as a thin veil obscuring the fact that it was actually the program of the CPY that had been adopted and implemented. As a mass organization, the PF also included non-communists, involving them in activities designed primarily by the CPY leadership, which ran the country. Only after 1948 the Party itself became more visible in the countryside, but the PF organizations kept their importance.

The socialist reconstruction of the rural areas implied revolutionary changes, and one can hardly argue that the PF local leaderships - notwithstanding the peasants themselves - were even familiar, not to mention conscientious, about the meaning and long term consequences of these changes. The collectivization was just the most remarkable issue of the day, but the PF organizations really had a hard time trying to persuade the farmers to introduce some technical innovations into their work and

51 AJ, SSRNJ, f. 19-57, Sednica Izvršnog odbora Narodnog fronta Jugoslavije, 28 septembra 1951 godine, (Discussion of B. Nešković). 
sometimes required exhausting agitation just to make small progress in a domain that obviously had nothing to do with the political sidings.

Particularly important was the role of the PF in forging the alliance between workers and small and middle peasants. This was materialized through mutual working visits exchanged between members of trade unions and members of farmers' cooperatives. However, in spite of the invested efforts, the activity of the PF was constantly weighed down by ideological constraints, formalism, a lack of insights into the problems, and an inclination toward futile violence. The initiatives were almost exclusively coming from the higher levels of the hierarchy, and convenient laudations were losing their persuasiveness confronted with the reality in the field, pregnant with problems, misconduct, lack of initiative, and distortion of policies, either through ideological zeal or complete carelessness.

\section{Sources and Literature}

\section{Unpublished sources}

- $\quad$ Arhiv Jugoslavije: Fond 142, Socijalistički savez radnog naroda Jugoslavije; Fond 507, Centralni komitet Saveza komunista Jugoslavije.

\section{Published sources}

- Броз, Јосип Тито. Говори и чланци, VII. Загреб: Напријед, 1959.

- Јовићевић, Мило. Улога и задаци Народног фронта на селу. Београд: Народни фронт Југославије, 1949.

- $\quad$ Kongres Narodnog fronta. [S. l., s. n.], 1945.

- Први конгрес ЈНОФ, Београд: Народни фронт Југославије, 1945.

- Седница Извршног одбора Народног фронта Југославије. Београд: Народни фронт Југославије, 1950.

- Програм курсева и кружока за организације Народног фронта у граду и селу. Београд: Земаљски одбор народног фронта Србије, 1949.

- Програм идеолошко-васпитних курсева и кружока за организације Народног фронта на селу. Сарајево: Комисија за идеолошко-васпитни рад Главног одбора народног фронта Босне и Херцеговине, 1949.

- $\quad$ Sednice Centralnog komiteta KPJ 1948-1952, eds Branko Petranović, Ranko Končar. Beograd: Komunist, 1995.

- Трећи конгрес Народног фронта Југославије. Београд: Борба, 1949.

- Упутство о организацији посебних бригада Народног фронта и Упутство о опремању, транспортовању и смјештају посебних бригада народног фронта. Сарајево: Државна штампарија, 1949. 
- $\quad$ IV конгрес Народног фронта Југославије (Социјалистичког савеза радног народа Југославије). Београд: Култура, 1953.

- $\quad$ конгрес Комунистичке Партије Југославије 21-28. јул 1948. Стенографске белешке. Београд: Култура, 1949.

\section{Newspapers and periodicals}

- $\quad$ Задруга

- Народни фронт

- Народно задругарство

- Партиска изградња

\section{Literature}

- $\quad$ Bokovoy, Melissa. Peasants and communists: politics and ideology in the Yugoslav countryside: 1941-1953. Pittsburgh: University of Pittsburgh Press, 1998.

- Z. Žepić, "Spor z Informbirojem in jugoslovanska kmetijska politika”. Jugoslavija v hladni vojni: zbornik Znanstvenega posveta Jugoslavija v hladni vojni, eds Jasna Fischer, Aleš Gabrič, Leonid J. Gibianskii, Edith S. Klein, 319-338. Ljubljana: Inštitut za novejšo zgodovino, 2004.

- $\quad$ Dimić, Ljubodrag. Agitprop kultura. Agitpropovska faza kulturne politike u Srbiji 1945-1952. Beograd: Rad, 1988.

- Dobrivojević, Ivana. Selo i grad. Transformacija agrarnog društva Srbije 1945-1955. Beograd: Institut za savremenu istoriju, 2013.

- Gaćeša, Nikola. Agrarna reforma i kolonizacija u Jugoslaviji 1945-1948. Novi Sad: Matica srpska, 1984.

- Гудац, Вера. Аграрна политика ФНРЈ и сељаштво у Србији 1949-1953. Београд: Завод за уџбенике и наставна средства, 1999.

- Kržišnik-Bukić, Vera. Cazinska buna: 1950. Sarajevo: Svjetlost, 1991.

- Milosavljević, Olivera. “Država i samoupravljanje: 1949-1956”. Doctoral thesis, University of Belgrade, Faculty of Philosophy, 1987.

- Милошевић, Срђан. “Аграрна политика Југославији 1945-1953”. Doctoral thesis, University of Belgrade, Faculty of Philosophy, August 2015. Accessed 1. 10. 2018. /https://fedorabg.bg.ac.rs/fedora/get/o:12950/bdef:Content/get

- Мирковић, Ена. “Благоје Нешковић (1907-1984). Политичка биографија". Doctoral thesis, University of Belgrade, Faculty of Philosophy, 2016. Accessed 1. 10. 2018. https://fedorabg.bg.ac.rs/fedora/get/o:15005/bdef:Content/get

- Митровић, Момчило. Изгубљене илузије. Прилози за друштвену истоpuју Србије. Београд: Институт за новију историју Србије, 1997.

- Павловић, Момчило. Српско село 1945-1952: откуп. Београд: Институт за савремену историју, 1998. 
- $\quad$ Petranović, Branko. Političke i pravne prilike za vreme privremene vlade DFJ. Beograd: Institut društvenih nauka, 1964.

- Petranović, Branko. “Osnivački kongres Narodnog fronta Jugoslavije”. Časopis za suvremenu povijest 1/1980, 5-15.

- $\quad$ Petranović, Branko. Politička i ekonomska osnova narodne vlasti u Jugoslaviji za vreme obnove. Beograd: Institut za savremenu istoriju, 1969.

- Petranović, Branko. "Narodni front u političkom sistemu Jugoslavije”. Istraživanja 8/1979, 309-399.

- Попов, Јелена. Драма на војвођанском селу (1945-1952): обавезни откуп пољопривредних производа. Нови Сад: Платонеум, 2002.

- Попов, Јелена. Народни фронт у Војводини 1944-1953. Нови Сад: Филозофски факултет, 1986.

- Sassoon, Donald. "Togliatti, Italian Communism and the Popular Front". The Polupar Front in Europe, eds Helen Graham and Paul Preston, 131-151. London: Macmillan, 1987.

- Spehnjak, Katarina. "Narodni front Jugoslavije: (SSRNJ - razvoj, programsko-teorijske osnove i procesi u društvenoj praksi 1945-1983)". Povijesni prilozi: zbornik radova 3/1984, 11-82.

- Spehnjak, Katarina. "Orijentacioni pregled i analiza izvora i literature o SSRNJ 1945-1978”. Časopis za suvremenu povijest 3/1980, 109-129.

- Veselinov, Dragan. Agrarno pitanje u Jugoslaviji: teorijsko-empirijska analiza položaja i uloge seljačkog gazdinstva u agrarnoj politici i privrednom razvoju Jugoslavije od 1918. do 1980. godine. Beograd: Borba, 1981.

- Troha, Nevenka. "Sobivanje ali soodvisnost Komunistične partije Slovenije in Osvobodilne fronte Slovenije (1945-1978)". Prispevki za novejšo zgodovino 1/2011, 241-270.

- Veselinov, Dragan. Sumrak seljaštva. Beograd: Ekonomika, 1987. 


\section{Summary}

The National Front of Yugoslavia was the most important organization for spreading the influence and implementing the policy of the CPY. The role of this organization was particularly important in rural areas because of its more comprehensive political structure, in view of the fact that rudimentary forms of capitalist commodity production had survived in the rural environment and also because Party membership among farmers was less massive than among workers. After the Informbiro Resolution in 1948, the role of the CPY became much more visible, but the People's Front organization in the rural areas was not neglected.

In a political sense, the key tasks of the People's Front were focused on the class struggle, while in the domain of contributing to the socialist reconstruction of rural areas, its mission was mainly concentrated on promoting the agrarian-political measures prescribed by the government, or rather, the Party. First of all, this included the cooperatives, the implementation of agro-technical measures, and cooperation between the private and socialist sector in the production process. No less importantly, the People's Front was supposed to be the mainstay of the alliance of workers and peasants, which was the key adage in the post-war phase of developing socialist relations.

The results of the People's Front in fulfilling its tasks were judged ambiguously: despite expressed acclaim, which prevailed on appropriate occasions, basically there was dissatisfaction among the party leaders with its achieved results. In actual fact, without clearly defined tasks or work methods, this organization, intended to rally the masses and direct the activity of the population, was not able to achieve any greater success, and its significance diminished with time. 


\title{
Резиме
}

\author{
Срђан Милошевић
}

\section{Улога Народног фронта Југославије у спровођењу мера аграрне политике југословенских комуниста на селу} (1945-1953)

\begin{abstract}
Апстракт: По завршетку Другог светског рата Народни фронт Југославије је развио широку делатност у сеоској средини, пратећи политичку линију Комунистичке партије Југославије (КПЈ). Сама партија избија у прве редове борбе за социјалистичку реконструкцију села тек од 1948/49. Захваљујући томе што су питања која су се односила на политику коју је југословенска власт спроводила према сељаштву играла значајну улогу у југословенско-совјетском раскиду, и Народни фронт (НФ) и КПЈ интензивирали су своје активности на селу и међу сељацима како би се дезавуисале совјетске оптужбе.
\end{abstract}

Кључне речи: Југославија (1945-1953), социјализам, комунисти, Народни фронт Југославије, сељаштво, село

Народни фронт Југославије био је најважнија организација за ширење утицаја и спровођење политике КПЈ. Улога ове организације била је на селу нарочито важна због своје свеобухватније политичке структуре, будући да су на селу опстајали рудиментарни облици капиталистичке робне производње, а чланство сељака у Партији било мање масовно него међу радништвом. После Резолуције Информбироа 1948. године улога КПЈ постала је знатно видљивија, али није занемарена ни народнофронтовска организација на селу.

Кључни задаци Народног фронта тицали су се, у политичком смислу - класне борбе, док су се у домену доприноса социјалистичкој реконструкцији села односили на промовисање аграрнополитичких мера власти, односно Партије. Ту су у првом реду спадали задругарство, примена агротехничких мера, сарадња приватног и социјалистичког сектора производње. Оно што је такође важно, Народни фронт је требало да буде носилац савеза радника и сељака, што је била кључна максима послератне фазе развоја социјалистичких односа. 
Резултати Народног фронта у испуњавању задатака оцењивани су амбивалентно: упркос изрицаним похвалама, нарочито у пригодним приликама, у основи је постојало незадовољство партијског врха постигнутим учинцима. Заправо, организација намењена масовном окупљању и усмеравању активности становништва, без јасно опредељених задатака и метода рада, није ни могла остваривати веће успехе, па је њен значај с временом опадао. 